\title{
Cost Of Unaccounted For Water - An Empirical Study In Tamil Nadu
}

\author{
Ramesh R1* and Narayanasamy N2* \\ ${ }^{1}$ Department of Rural Development,Bahir Dar University,Bahir Dar, Ethiopia \\ ${ }^{2}$ Gandhigram Rural University, Gandhigram - 624 302, Tamil Nadu, India
}

\begin{abstract}
In Tamil Nadu state, India, it is the responsibility of the state government to provide drinking water to every household. This is carried out through the lowest elected government at the village level. Of late, the government puts into practice concepts like Demand Driven Approach, which demands the community contribute financially for any social infrastructure to be created, including drinking water supply. This approach seems to give financial matters the overriding priority blinding all the other realities such as actual requirement as per technical standards, and responsibilities of Operation and Maintenance etc. That means being able to contribute financially puts the local community in a position to get water supply infrastructure even excessive of the technical norms. This results in excessive draft of ground water resulting in wastage of fresh water. Especially in a piped water supply system, the water pumped from the ground whether they are used or wasted has an economic value - as this is a service provided using electric power. It is found through an empirical study that the community is insensitive to the cost of water wasted. This study conducted in 17 villages found that all the 17 Village Panchayats (village administrative units) put together, on an average 35 per cent of the water pumped is either excessively used or wasted. It means merely by being judicious in the use of water, each Panchayat has the potential of saving approximately one-third of the expenses incurred on water service delivery. The research paper elaborates this point.
\end{abstract}

\section{Introduction}

The physical infrastructure of a water supply system that enables the access, availability, and adequacy of water to the user community determine the technical capacity of the water supply system. In a community-managed water supply system, technical management of the system depends on proper operation and maintenance of the physical infrastructure in order to ensure uninterrupted distribution of safe water in adequate quantity. Hence, technical management partly depends on technical capacity and partly depends on human capacity to manage the technical installations. Technically, this is often referred to as system efficiency. Every public water system piped water supply or handpump - has unique physical characteristics that help determine the type and level of operations, maintenance, and other actions necessary to ensure supply of safe drinking water $[1,2]$. One acceptable way to ascertain system efficiency is to compare the actual delivery (output) against the standard water supply norms in vogue. In other words, comparing what the user community takes delivery of against the standard water supply norms is one dependable measure of performance.

\section{Rural Water Supply in India}

Water is a state subject in India. The state implements schemes for providing drinking water facilities. The Central Government supplements the efforts of the states by providing financial and technical support. The Tenth Plan envisaged provision of safe drinking water to all rural habitations. A major programme - 'Accelerated Rural Water Supply Programme (ARWSP)' is being implemented since 1972-73 towards achieving this objective. The Government of India has spent over Rs.50,000 crores (up to March 31, 2005), in order to meet the drinking water needs of the rural population. As of now, more than 3.7 million handpumps and 1.73 lakh piped water schemes have been installed in rural areas in various states.

As on April 1, 2005, 96.1 per cent of rural habitations were fully covered, and 3.6 per cent were partially covered, leaving 0.3 per cent uncovered with drinking water facility. However, there is variation in the state-wise coverage of habitations resulting in some states lagging behind, while others have reached almost 'near full coverage norm'. ARWSP [3], currently being implemented through the Rajiv Gandhi National Drinking Water Mission, aims at full coverage of all rural habitations with population of 100 and above. Although investments are continuously made on building new technical structures or for rejuvenating existing technical structures, it is realized, often times, that adequate operation and maintenance $(\mathrm{O} \& \mathrm{M})$ is critical for sustaining water supply systems already created [4]

\section{Rural Water Supply in Tamil Nadu State}

Tamil Nadu State has 385 Development Blocks consisting 12,619 Village Panchayats covering 81,787 habitations. As per TWAD Board's Resurvey, as of January 2003, [5-6] there were 46,037 Power Pump Schemes and 1,39,262 Hand Pump Schemes. Most of the rural water supply schemes use groundwater as the source through borewells, tubewells and openwells. Of the 81,787 habitations, 36,767 habitations ( 45 per cent) are classified as "fully covered" each person in a habitation gets 40 litres of water per day. 36,064 habitations (44 per cent) stand as "partially covered" each person in a habitation receives 10 to 39 litres of water per day. 8,956 habitations (11 per cent) are classified as "not covered" each person gets 0 to 9 litres of

*Corresponding author: R Ramesh,Assistant Professor,Department of Rural Development,Bahir Dar University,Bahir Dar, Ethiopia, E-mail: ramesh.gri@gmail. $\underline{\text { com }}$

N Narayanasamy,Head, Department of Extension Education,Gandhigram Rural University, Gandhigram - 624 302,Tamil Nadu, India, E-mail: nnvi2002@yahoo. com

Received August 27, 2010; Accepted October 14, 2010; Published October 14, 2010

Citation: Ramesh R, Narayanasamy N (2010) Cost Of Unaccounted For Water - An Empirical Study In Tamil Nadu. J Waste Water Treatment Analysis 1:103. doi:10.4172/2157-7587.1000103

Copyright: (c) 2010 Ramesh R, et al. This is an open-access article distributed under the terms of the Creative Commons Attribution License, which permits unrestricted use, distribution, and reproduction in any medium, provided the original author and source are credited. 
water per day. Among the 'not covered habitations' 5574 habitations have no safe source of water [7]. This analysis indicates that the State Government of Tamil Nadu, through centralized implementation, has provided either motor-driven or hand pump schemes from bore-wells or open wells in 89 per cent of the 81,787 hamlets.

It was categorically stated earlier that over the years, the government has made huge investments in constructing domestic water supply installations. With the major investments on water sector during the past two decades ${ }^{1}$, the emphasis has been mainly placed on new construction in rural areas. The maintenance of the power pumps is taken care of by the TWAD Board, although not in the scale required. In practice, taking into consideration the failure of handpumps due to depleting water table, the TWAD Board has given up installing handpumps since 1985. Instead, the Board has introduced the concept of mini-power pump scheme since 1996 for habitations with a population of around 150 . However, the DRDAs through Block Development Offices and Village Panchayats continue to install handpumps wherever it is found to be technically feasible. Handpumps are installed especially for the purposes of serving some isolated settlements /habitations or if the functionality of the piped water supply system is unreliable due to reasons such as frequent power failure. The maintenance of the handpumps is handled by the Handpump Fitters posted at Block Development Offices throughout the state [8-10].

Major capital investment expenditure, rejuvenation of technical installations, and replacement of worn out installations used to be state-managed. After the $73^{\text {rd }}$ Constitutional Amendment Act 1992 became operational in Tamil Nadu, the Tamil Nadu Panchayats Act - 1994 spells out that the Village Panchayats should take up the responsibilities of Operation and Maintenance of water supply system to the population in the jurisdiction of Village Panchayats. The fact is that Village Panchayats are not technically capacitated nor are adequately prepared to take up the financial responsibilities associated with Operation and Maintenance of water supply infrastructure. The outcome is under-priced water services, resulting in continuous deterioration of the facilities created. As a result the government has to continue reinvesting in constructing new schemes and rehabilitation of the existing schemes diverting its scarce resources meant for still unreached communities. Therefore, in practice everything is centralized and state-managed [11].

In order to overcome the problems in centralized state-managed water supply, an alternative model with 'Community Management' as the central idea has been introduced by some of the state governments. For instance, the State governments of Tamil Nadu and Karnataka have implemented community-managed water supply system in a few districts through bi-lateral arrangement with agencies such as the Dandia. The model proposed aims mainly at capacity building of Village Panchayats to enable them take up the responsibility of Operation and Maintenance of water supply system. The Rajiv Gandhi National Drinking Water Mission of the Government of India has made similar attempts through Sector Reform Programmes. The Government of India, as part of structural adjustment programmes, has floated a similar idea which is called Swajaldhara, with the financial and technical assistance of the World Bank, where the local government is expected to take up the responsibility of providing water and Operation and Maintenance of the physical structures [12].

One basic assertion that all these programmes make is: as far as rural water supply is concerned expected level of service has not been reached due to (a) deficiencies in operation and maintenance of the systems; and (b) absence of involvement of the user community [13]. The capital invested is eroded as gradual deterioration of the facilities is taking place. This generally results in villages that are once considered as fully covered falling back as partially covered [14]. Improper operation and absence of maintenance again results in partially covered ones falling into the category of zero water access villages. Besides inadequate government financial and technical support; low quality of work, inadequate management capacity and lack of community involvement and ownership are often cited as reasons for this situation [15].

\section{Status of Technical Management in the Study Villages}

The approach, introduced by the Danida WS Project, aimed at establishing an autonomous community based maintenance system, which can handle all water supply facilities independently of external assistance [16]. That is community management of water supply system through local bodies in place of state managing the system for the user community. Technical management of water supply system is one of the important facets in any water supply scheme. This Chapter analyses the technical factors which are likely to influence community-managed water supply system including technology choice, operation and maintenance, and service level. [17].

\section{Technology Choice}

A salient feature of the Danida Project [18] on drinking water service and sanitation is, it adopted Demand Driven Approach (DDA). As per the Project Document of Danida the community should be prepared to pay one seventh of the capital cost so as to become eligible to obtain project assistance. In other words, for a water supply scheme of Rs.7 lakhs, the user community should be prepared to locally mobilize and contribute Rs. 1 lakh. This entails community participation in financing the scheme as well as making available the type of technology the community demands based on the service level desired. It includes: creating a new water source through bore wells and open wells, construction of pumping main, pump room, service reservoir of various capacities, repairing and relaying of existing distribution lines, extension of pipe lines to unserved areas, construction of additional standposts (public fountains), and installation of handpumps [19-20].

Under the DDA, the range of feasible technologies should be presented to the community, the advantages and disadvantages of each discussed, including liabilities for maintenance costs, simplicity of operation and maintenance, and the risks of contamination of water. The final choice should be for the community to make [21].

An analysis of the determinants of technology choice revealed that 'community affordability of contribution towards capital cost' is

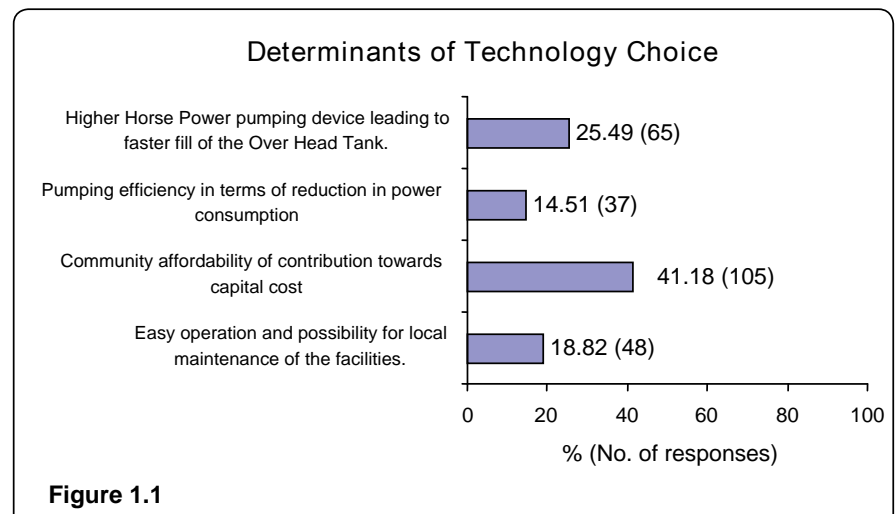


the major factor. The second important factor, as reported by 25 per cent of the respondents is: higher duty pumping device that helps faster fill of the Over Head Tank'. Aspects such as 'easy operation and possibility for local maintenance of the technology demanded' and 'pumping efficiency in terms of reduction of power consumption' remain third and fourth in the order of determining the technology choice ( Figure 1.1). It proves that only the financial affordability towards capital cost contribution rather than standard service norms that determines the technology choice. The community while determining the technology does not consider matters such as easy Operation and Maintenance, and the essentiality of reduction in power consumption. The mindset of demanding higher horsepower pumping device so as to pump groundwater to the OHT at a faster rate is considered important rather than trying to understand that a higher horse power water lifting device would lead to: (a) more wastage of water, (b) heavy electricity bill, and (c) faster depletion of groundwater.

\section{Population-size vis-à-vis Reservoir Capacity}

The capacity of the Over Head Tank, otherwise known as service reservoir is technically determined based on the population it is supposed to serve. Calculated thus, the population-size vis-à-vis the size of the storage reservoir is given in (Box 1.1), [22].

\begin{tabular}{|cc|}
\multicolumn{2}{c|}{ TWAD - 1.1 } \\
TWural Water Supply Norms for OHT \\
Population : Less than 150 & $:$ Mini Power Pump \\
Population : Above $150-500$ & $: 10,000$ Litre OHT \\
Population : $501-1250$ & $: 30,000$ Litre OHT \\
Population : $1251-2500$ & $: 60,000$ Litre OHT \\
Population : $2501-5000$ & $: 100,000$ Litre OHT \\
Source : Government of Tamil Nadu TWAD Rural Water Supply Norms for OHT
\end{tabular}

Water demand calculation was made for all the 17 Village Panchayats under study to find out if the villages that the WS Project assisted really required improvement in technical infrastructure. In order to do this exercise, the size of Over Head Tank was taken as the important indicator, based on the premise that everything else such as length of distribution line, number of pumping devices, service level etc. most often depend on the number and size of the service reservoir.

An analysis of population vis-à-vis the facilities (Over Head Tank) (Table 1.1) shows that the existing capacity of the OHTs in 14 of the 17 Village Panchayats is more than the standard requirement (see Box -1.1 for the standards). Only one Village Panchayat (i.e. Guruvappanpettai) has the right size OHT as per the standard norm. Two Panchayats where the facilities are less than the requirement, the shortage in piped water supply arrangement is made up by the excess number of handpumps. In 8 of the 17 Panchayats, the size of the OHT is larger than the requirement by more than 100 per cent. It is logical to think that more the facilities, more the expenses on maintenance; similarly, more the facilities, more the chances of wastage of water, which would result in higher operation expenses for the Village Panchayat. Either way, it adds to the $O \& M$ expenditure of the Village Panchayat. [23-24]

Several pertinent questions crop up here:

- If the concept of Demand Driven Approach takes into account only the financial capacity of the community to pay the community share of the capital cost; and doesn't it take into account if the community really requires the facilities that they demand. In other words, the WS Project seems to have failed to distinguish between fulfilling a 'need' and satisfying a 'want'.

\begin{tabular}{|c|c|c|c|c|c|c|c|}
\hline 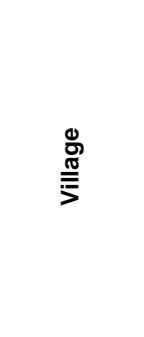 & 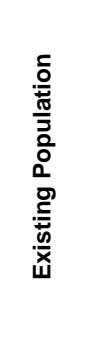 & 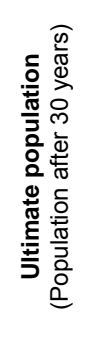 & 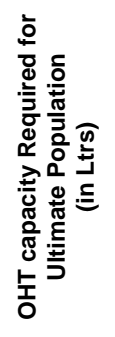 & 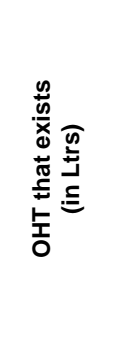 & 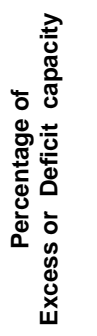 & 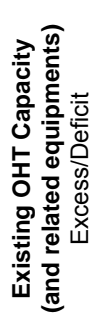 & 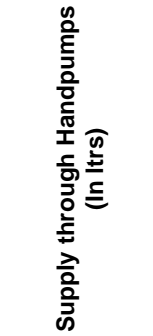 \\
\hline Sathyavadi & 3,314 & 4,639 & $1,00,000$ & $2,15,000$ & $115 \%$ & Excess & $44,000(11)$ \\
\hline Palakollai & 4347 & 6085 & $1,30,000$ & $1,60,000$ & $23 \%$ & Excess & $16,000(4)$ \\
\hline Karuvep'ku & 3089 & 4325 & $1,00,000$ & $2,10,500$ & $110 \%$ & Excess & $24,000(6)$ \\
\hline Koonankuri & 1851 & 2591 & 60,000 & 67,500 & $13 \%$ & Excess & 0 \\
\hline Valakollai & 1504 & 2106 & 30,000 & 65,000 & $116 \%$ & Excess & $36,000(9)$ \\
\hline Keerap. & 3747 & 5246 & $1,10,000$ & $2,85,000$ & $159 \%$ & Excess & $1,68,000(42)$ \\
\hline Valuthalam & 8,076 & 11,306 & $2,30,000$ & $4,80,000$ & $108 \%$ & Excess & $16,000(4)$ \\
\hline Sirupalyur & 1239 & 1735 & 60,000 & 90,000 & $50 \%$ & Excess & $28,000(7)$ \\
\hline Kannankudi & 1,724 & 2,414 & 60,000 & $1,50,000$ & $150 \%$ & Excess & $60,000(15)$ \\
\hline Vattathur & 1,626 & 2276 & 60,000 & 40,000 & $50 \% \mathrm{D}$ & Deficit & $32,000(8)$ \\
\hline Ramanath & 4,745 & 6643 & $1,30,000$ & $2,30,000$ & $77 \%$ & Excess & $64,000(16)$ \\
\hline Adari & 2658 & 3721 & $1,00,000$ & $1,55,000$ & $55 \%$ & Excess & $60,000(15)$ \\
\hline Kandamath & 1207 & 1690 & 60,000 & $2,50,000$ & $316 \%$ & Excess & $36,000(9)$ \\
\hline Pattur & 1162 & 1627 & 60,000 & 65,000 & $8 \%$ & Excess & $36,000(9)$ \\
\hline Guruvap & 832 & 1165 & 30,000 & 30,000 & 0 & Right & $8000(2)$ \\
\hline Aranthangi & 2987 & 4182 & $1,00,000$ & 90,000 & $11 \% \mathrm{D}$ & Deficit & $24,000(6)$ \\
\hline Sakkankudi & 1257 & 1760 & 30,000 & 60,000 & $100 \%$ & Excess & $72,000(18)$ \\
\hline
\end{tabular}

Note: (1) TWAD Board has it as a design principle to plan for a population projection of the next thirty years which is called ultimate population in TWAD Board's

language. 4000 litres of water a day.

Table 1.1 : Size of Population Vis-à-Vis Facilities. 
- How did the demand of the community, prepared in the form of a proposal, pass a technical sanction, when the facilities that existed in many of the villages are more than what is technically permissible? Is everyone, including those holding high offices offering technical sanction, concerned more about convincing the community to pay community share towards capital cost in order to count that a scheme with community participation is implemented.

- Would the technology demanded by the community be a burden on the community in terms of maintenance expenditure? What is the justification to pronounce technically that a given community really requires additional facility through deploying additional funds, and that rejuvenation of existing facility would prove insufficient to cater to the requirement? These are some of the questions that do not seem to be raised.

It can be inferred that in implementing concepts like Demand Driven Approach, making the community contribute financially seem to give financial matters the over-riding priority. The infrastructure that is technically required as per the standard norms taking into consideration the groundwater position of the area, and water demand of a given population as per the existing rural water supply norms do not seem to be paid attention. In other words, making the community contribute financially is taken as an achievement, which blinds all other realities such as actual requirement as per technical standards, and responsibilities of Operation and Maintenance etc.

\section{Operation and Maintenance $(0 \& \mathrm{M})$}

A water supply facility is sustainable: (i) when it functions and is being used; (ii) when it is able to deliver an appropriate level of service; and (iii) when it can be operated and maintained at local level with limited but feasible external support. Operation usually means the everyday running and handling of a water supply system to convey safe water to the users. Maintenance means the activities required to sustain the water supply in a proper working condition [25].

Coverage, accessibility, availability, potability, and adequacy of water to a given population are usually referred to as 'Service Level'. Therefore, it includes both qualitative as well as quantitative standards. Water Tariff structures differ depending upon the level of service households choose to enjoy. A household may choose to own a yard tap (House Service Connection) and it may be prepared to pay a higher amount in terms of water tariff; whereas poor families may choose to take water from a public water collection point and so, they pay comparatively a lesser amount. It is appropriate to mention here that service level is a factor that is completely dependent on proper Operation and Maintenance $(\mathrm{O} \& \mathrm{M})$ of the technical infrastructures.

\section{Service Level - Coverage}

By coverage is meant the number of people who receive water

Total Water Users - as HSC holders and PF users

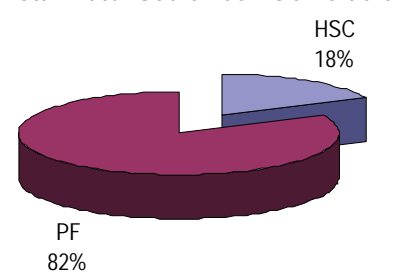

Figure 1.2

\section{BOX - 1.2
Rural Water Supply Tamil Nadu - Design Criteria}

The government norm for rural water supply in Tamil Nadu is that the HSC holders should get $55 \mathrm{lpcd}$, and PF users should get $40 \mathrm{lpcd}$ water. The water supply design criteria are that 40 Ipcd for 70 per cent of the population through standposts (PFs), and 70 Ipcd for 30 per cent of the population through HSCs. Average design made is usually for $55 \mathrm{lpcd}$.

supply service and the mode of delivery (or distribution) of water to individual households. Coverage objective is usually based on what the community members want and are willing to pay for, as well as social and environmental consideration [26]. The technologies that are found for water delivery in the study villages are: (a) House Service Connection (yard taps), (b) Public Fountains (common water collection points for every $10-15$ families); and (c) Handpumps which simply require human energy to lift water from the ground ${ }^{2}$.

For the purpose of analysis only those who collect water from HSCs and PFs are taken into account. Handpumps are mostly used as stand-by source of water when there is power failure, and when getting piped water supply is not possible. There is hardly anybody who is dependent exclusively on handpumps alone as a source of drinking water. And, handpumps, as a facility that provides water in a common water collection point, are taken for discussion where appropriate. 13 of the 17 villages have Scheduled Caste (SC) Colonies. In all the 13 villages, SC Colonies have been provided with separate service reservoir (Over Head Tank) or extension of water distribution line from the main village. Therefore, the discussion regarding accessibility, availability and adequacy refer not to only those in the main settlement in a given Panchayat, but also to those who reside in the SC Colonies as well.

There are 10, 712 households (water users) in the selected Village Panchayats. All the households get water. Around 82 per cent of them use Public Fountains, and the remaining 18 per cent are HSC holders (Figure 1.2). Coverage-wise there are no habitations within Village Panchayats or households within habitations which remain uncovered in getting water service. The government norm for rural water supply in Tamil Nadu (Box 1.2)[27-28], is that the HSC holders should get $55 \mathrm{lpcd}$, and PF users should get $40 \mathrm{lpcd}$ water ${ }^{3}$. Discussing about the categories of water users in the study villages, accessibility, availability, and service levels (adequacy of water) are three important technical features that require to be analysed.

\section{Service Level - Quantity}

Accessibility: One of the common aims of many water projects is to reduce the distance that people carry water because that task is tiring, time consuming and has negative long-term effects on health [29]. Therefore, the distance to the water collection point determines to a considerable extent, if a water supply scheme should be undertaken at all and which technology is the best when thus selected. The Government of India has fixed the norm of providing water within $1.6 \mathrm{KM}$ distance for rural households (Gol-RGNDWM, 2004). Today, it is reported that 80 per cent of the households in the country has protected water source within a distance of 1 K.M [30].

The situation in the study villages with regard to accessibility is that in 14 out of the 17 villages studied, people have accessibility to a Public Fountain or a Hand Pump within 200 metres. Only in three villages people walk up to 500 metres to collect drinking water. There is no village where people walk more than 500 metres for the purpose of collecting protected water (Figure 1.3). Two things need to be borne in mind here. One is that this refers to PF and HP users only and the HSC holders have access to water supply facility at their yard 
itself, and the other is that the statement made about the distance from where water is collected holds good for the Scheduled Caste community also who are usually inhabitants of isolated settlements from the main village, often addressed as: 'SC Colonies'.

Availability: Availability tells about the hours water is delivered to the community members - be it HSC holders or PF users. This means that all the community members have access to a water supply facility by no means implies that they have easy access to water service, or water is made available to them. Access to water supply facility is one and actual availability of water is another. This is to say that mere access to a facility does not ensure availability of service from that facility. If there are physical facilities available within an appreciable distance but water service delivery is poor due to absence of arrangements for operation in designated hours, it would be of little use to the community members. Therefore, the hours community members get water delivered through their yard taps or common water collection points is a matter for study.

In 7 of the 17 villages water is made available to PF users and HSC holders for almost six hours daily - three hours in the morning and three hours in the evening. In five villages water is made available for four hours - two hours in the morning and two hours in the evening (Table 1.2). Certain interesting things to note are: (a) there is no village where water is considered so scarce that they deliver water on alternate day or twice a week like it is done in some Tamil Nadu villages; (b) nor are there villages where water flows anytime one opens the tap without any regulation. These are indications of at least some control and regulation being exercised in these villages. However, the hours water is made available could be: (i) reasonable as per the norms prevailing in the state; (ii) it could be less than the standard norms; or (iii) it could be more than the standard norms.

Adequacy: Adequacy of water supply is one of the main indicators of service level of a water supply system. The coverage norm for

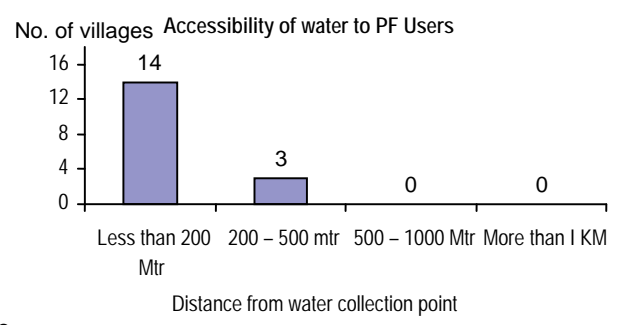

Figure 1.3

\begin{tabular}{|c|c|c|}
\hline \multicolumn{1}{|c|}{ Hours of Water Availability } & No. of Villages & Per cent \\
\hline $4(M)+4(E)=8$ Hours a day & 2 & 11.76 \\
\hline $3(M)+3(E)=6$ Hours a day & 7 & 41.17 \\
\hline $2(M)+2(E)=4$ Hours a day & 5 & 29.41 \\
\hline $1(M)+1(E)=2$ Hours a day & 3 & 17.65 \\
\hline Total villages studied & $\mathbf{1 7}$ & $\mathbf{1 0 0}$ \\
\hline
\end{tabular}

Note: $M$ = Morning: $E$ = Evening

Source: Data received from Power Pump Operators

Table 1.2: Water Availability.

\begin{tabular}{|c|c|c|c|c|}
\hline Service Level (in Lrs) & PF & Percentage & HSC & Percentage \\
\hline $0-9$ (Not covered) & - & 0.00 & - & 0.00 \\
\hline $10-39$ (Partly Covered) & - & 0.00 & - & 0.00 \\
\hline $40-55$ (Fully Covered) & 6 & 35.29 & - & 0.00 \\
\hline $56-70$ (Optimal Use) & 8 & 47.06 & 1 & 5.88 \\
\hline $71-90$ (Excessive Use) & 1 & 5.88 & 5 & 29.41 \\
\hline $91-109$ (Excessive Use) & 1 & 5.88 & 4 & 23.53 \\
\hline $110<$ (Excessive Use) & 1 & 5.88 & 7 & 41.18 \\
\hline Total & $\mathbf{1 7}$ & $\mathbf{1 0 0 . 0 0}$ & $\mathbf{1 7}$ & $\mathbf{1 0 0 . 0 0}$ \\
\hline
\end{tabular}

(No of Villages)

Table 1.3: Service Level.
Service Level to PF \& HSC Users

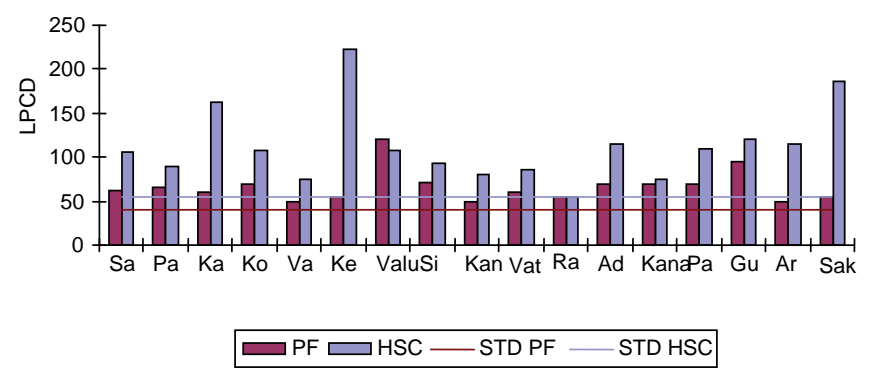

Figure 1.4

\begin{tabular}{|lll}
\hline \multicolumn{2}{c}{ Box - 1.3 } \\
\multicolumn{4}{|c|}{ Coverage Norms (Ipcd) - Tamil Nadu } \\
$0-9$ & : Not covered & : Zero Access \\
$10-39$ & : Partially Covered (Rural) & : Basic Access \\
$40-55$ & : Fully Covered (Rural) & : Intermediate Access (Target for VPs) \\
$56-70$ & : Town Panchayats & : Optimal Access (if used at VP level) \\
$71-90$ & : Municipalities & : Excessive Use (if used at VP level) \\
$91-109$ & : Corporations & : Excessive Use (if used at VP level) \\
$110<$ & : Metropolis & : Excessive Use (if used at VP level)
\end{tabular}

Source: Department of Municipal Administration and Water Supply (MAWS), GoTN.

rural areas is that 40 lpcd for PFs, and 55 lpcd for HSCs. However, the Government of India states that once the task of providing every village with at least one source of safe drinking water is completed, the enhancement and expansion process may be initiated to provide 55 lpcd to all PF users, and 70 lpcd to all HSC holders. Similarly, the norm pertaining to distance can also be reduced from $1.6 \mathrm{KM}$ to 0.5 KM (Gol-RGNDWM, 2004) (Box 1.3).

The service level to PF users and HSC holders in all the selected Panchayats was studied. The PF users in eight (47 Per cent) of the 17 Panchayats under study get optimal water supply meaning, the best possible water service that HSC users ought to get is being enjoyed by the PF users for which, in many of the Panchayats they are not required to pay [Table 1.3]. The PF users in three Panchayats viz. Sirupalyur, (72 lpcd) Guruvappanpettai (95 lpcd) and Valuthalampattu (120 lpcd), enjoy water service almost to the level of Municipalities, Corporations and Metropolis respectively [31-32].The average quantity of water supplied to PF users is $66 \mathrm{lpcd}$. This is definitely excessive draft of water. The reason found was that water was used for purposes other than, for which it was meant such as: washing of utensils, cleaning of cloths, watering of plants, and kitchen garden etc. In some of the common water collection points it was reported that domestic animals are given bath, and school children playing with open taps is also taken nonchalantly.

The state of affairs with regard to HSC holders is not different. Sixteen out of the 17 Village Panchayats get more than the standard norms i.e. more than $55 \mathrm{lpcd}$. It is only in one Village (Ramantham) HSC holders get 55 lpcd which is exactly the right quantity as per the existing norms. Seven Village Panchayats use more than $110 \mathrm{lpcd}$, which is the water service norm for the Metropolitan cities in India or double the amount of the standard quantity (Figure 1.4). The average quantity of water supply to HSC holders works out to $112 \mathrm{lpcd}$.

Thus, in all the 17 villages the water made available through public fountains is more than the standard norm of $40 \mathrm{lpcd}$. They have already reached the dream target of the RGNDWM of providing 
55 lpcd to PF users. Similarly, except Ramanatham Village Panchayat where HSC holders are getting 55 lpcd as per the standard norm, in all other Village Panchayats the HSC holders are already getting the Government of India's dream target of 70 lpcd and more. However, one should look at the cost (EB Bill) incurred by the Panchayat in pumping the water to OHT and distributing it to the users.

One example is where Keerapalayam and Sakkankudi (both fall under Keerapalayam Block of Cuddalore district) HSC users can do with $70 \mathrm{lpcd}$ are doing with $223 \mathrm{lpcd}$ and $187 \mathrm{lpcd}$ respectively. This definitely reflects in the EB bill these Panchayats are paying. The unaccounted for water (water being wasted) is very high in these two villages. Over use or wastage of water, apart from bringing a hefty EB Bill to the Panchayats leads to the danger of the source drying up soon. Keerapalayam Block although is 'safe' in groundwater potential, it may soon fall under the 'semi-critical' category if pumping of groundwater continued at this rate. [33].

Another point of question is if PF users get sufficient water for which they do not have to pay - neither a caution deposit to the Village Panchayat nor monthly water charges - would they show interest in availing a HSC paying all that requires to be paid statutorily. If the Village Panchayat made efforts to augment the income providing more HSCs there would be hardly any takers.

\section{The Deviation from the Water Supply Norm}

In order to understand the extent of deviation, in absolute as well as in per centage terms, from the standard water supply norms of the Government of Tamil Nadu, Standard Deviation and Coefficient of Variation were worked out. These calculations have been made from the actual average water supply, in order to assess the standard deviation and co-efficient of variation in the actual water supply in the study villages. The results of the SD and CV calculated based on the actual mean and the water supply standards are presented in (Table 1.4).

In all the 17 Village Panchayats PF users are getting water supply

\begin{tabular}{|l|c|c|}
\hline & PF & HSC \\
\hline Mean (norm) & 40 & 55 \\
\hline Mean (actual) & 66.41 & 112.18 \\
\hline SD (norm) & 31.56 & 70.66 \\
\hline SD (actual) & 17.81 & 42.79 \\
\hline CV (norm) & 78.90 & 128.47 \\
\hline CV (Actual) & 26.82 & 38.14 \\
\hline
\end{tabular}

Table 1.4: Extent of Deviation from (Standard and Actual) Norms.

\begin{tabular}{|c|c|c|c|c|c|c|}
\hline Village & PF & $\begin{array}{c}{ }^{*} \mathbf{X} \\
\text { (PF- 40) }\end{array}$ & $\mathbf{X}^{\mathbf{2}}$ & HSC & $\begin{array}{c}{ }^{*} \mathbf{X} \\
\text { (HSC-55) }\end{array}$ & $\mathbf{x}^{\mathbf{2}}$ \\
\hline Sathyavadi & 62 & 22 & 484 & 105 & 50 & 2500 \\
\hline Palakollai & 65 & 25 & 625 & 90 & 35 & 1225 \\
\hline Karuvepilankurichi & 60 & 20 & 400 & 163 & 108 & 11664 \\
\hline Koonakurichi & 70 & 30 & 900 & 108 & 53 & 2809 \\
\hline Valakollai & 50 & 10 & 100 & 75 & 20 & 400 \\
\hline Keerapalayam & 55 & 15 & 225 & 223 & 168 & 28224 \\
\hline valuthalampattu & 120 & 80 & 6400 & 108 & 53 & 2809 \\
\hline Sirupalaiyur & 72 & 32 & 1024 & 93 & 38 & 1444 \\
\hline Kannankudi & 50 & 10 & 100 & 80 & 25 & 625 \\
\hline Vattathur & 60 & 20 & 400 & 85 & 30 & 900 \\
\hline Ramanatham & 55 & 15 & 225 & 55 & 0 & 0 \\
\hline Adari & 70 & 30 & 900 & 115 & 60 & 3600 \\
\hline Kanadamathan & 70 & 30 & 900 & 75 & 20 & 400 \\
\hline Pattur & 70 & 30 & 900 & 110 & 55 & 3025 \\
\hline Guruvappanpettai & 95 & 55 & 3025 & 120 & 65 & 4225 \\
\hline Aranthangi & 50 & 10 & 100 & 115 & 60 & 3600 \\
\hline Sakkankudi & 55 & 15 & 225 & 187 & 132 & 17424 \\
\hline & & Sum & 16933 & & & 84874 \\
\hline & SD & Sum/N & 996.0588 & & & 4992.588 \\
\hline & CV & SD/40*100 & $\mathbf{7 8 . 9 0}$ & & & $\mathbf{1 2 8 . 4 7}$ \\
\hline
\end{tabular}

Since we need to analyse only the deviation from the standard norm, instead of actual mean, the standard norm for service level in rural areas is taken. $\mathrm{SD}=\sqrt{\Sigma} \mathrm{x}^{2} / \mathrm{N}$

Table 1.5: Extent of Deviation from Norms.
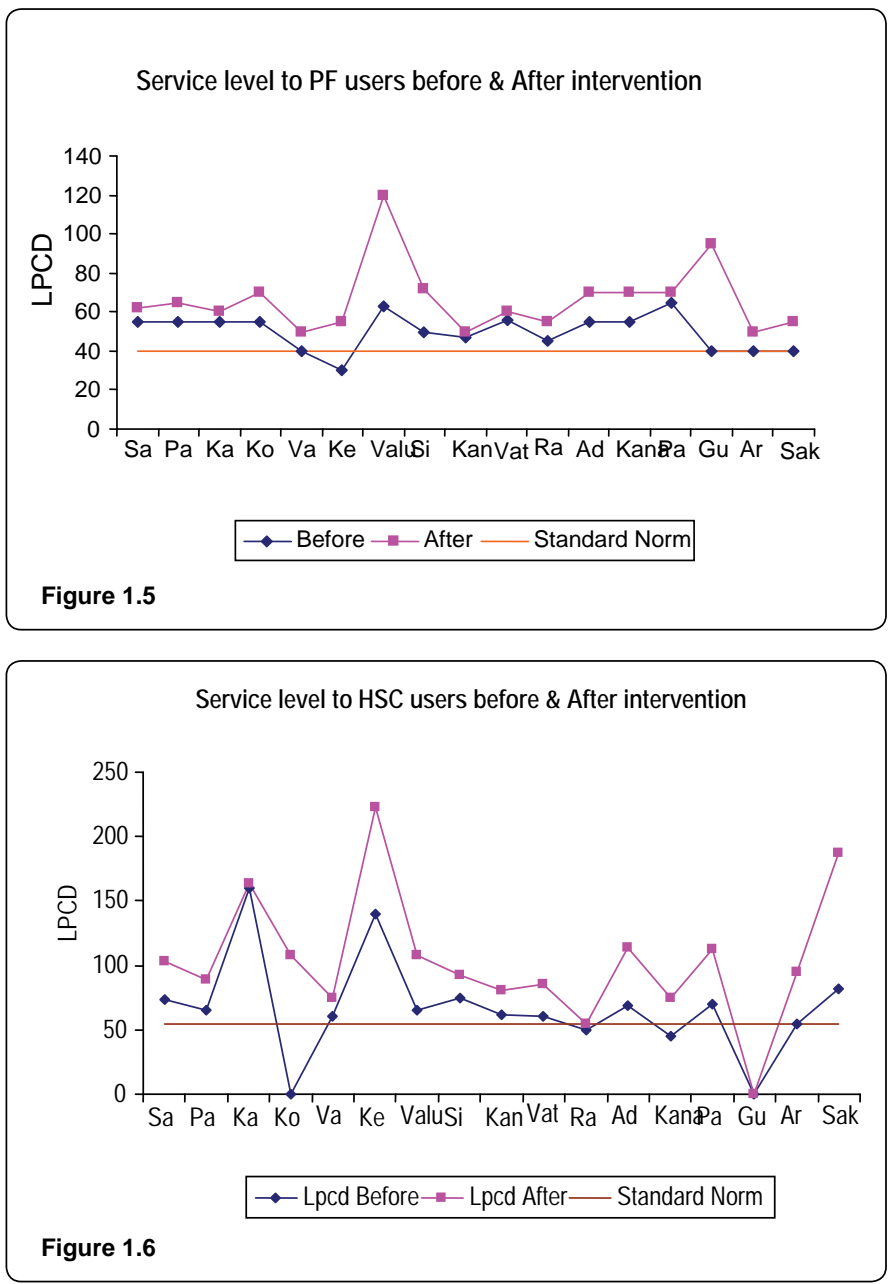

more than what they should be getting as per the standard norm (i.e.40 lpcd). But, the actual supply in these villages vary from $50 \mathrm{lpcd}$ to $120 \mathrm{lpcd}$ with an average of $66.41 \mathrm{lpcd}$ [Table 1.5]. The average water supply being 65 per cent higher than the standard water supply of 40 lpcd in the case of PF users.

The HSC holders are also getting more than what they should be getting as per the standard norm. The supply to HSC holders ranged between 55 lpcd to 223 lpcd. The average quantity supplied through the source was $112.18 \mathrm{lpcd}$ which is about two times of the standard norm recommended by the government. The standard deviation in the water supply quantity were $31.56 \mathrm{lpcd}$ in the case of PF users, and 70.66 lpcd in the case of HSC holders from the standard norm of 40 lpcd and 55 lpcd respectively. As a result the co-efficient of variation works out to 78.90 per cent and 128.47 per cent respectively. Thus, vast variations are found in the water supply through HSC among the study villages. This is proof again that excessive use of water is prevalent both by the PF users as well as by the HSC holders.

\section{Analysis of Quantity Supplied}

Quantity-wise if both PF users as well as HSC holders are getting more than the standard norms recommended by the Government of Tamil Nadu, another question arises, if the WS Project intervention was required at all in the first place. What was the service level before the intervention that necessitated the WS Project to make this intervention? The service level before the Project intervention, and service level after the intervention in the study villages were plotted 
on graph sheets separately for PF users (Figure 1.5) and HSC holders (Figure 1.6).

The service level in almost all the villages, barring one village (i.e. Keerapalayam), has been sufficient. That is PF users even before the Project intervention were getting sufficient quantity of water, as per the official norms of the Government of Tamil Nadu.

The service level to HSC holders in 15 of the 17 villages studied either matched the standard norms (i.e. 55 lpcd) or was more than the standard norms, even before the Project intervention. The two villages that really required assistance for improvement in technical infrastructure so as to provide the minimum $55 \mathrm{lpcd}$ water to the community members were Ramanatham and Kandamathan. Two other villages (viz. Koonankurichi and Guruvappanpettai) had zero HSC holders before. Koonankurichi has provided House Service Connections with the assistance of the Project where as Guruvappanpettai did not. In the ultimate analysis it appears that many of the villages under study did not require improvement in service levels, as they were already getting enough water or more compared against the standard water supply norms. Then, what necessitated the community to demand project assistance, and what required the WS Project Management to oblige to the demand of the community require further discussion.

Discussion with the Panchayat functionaries revealed that the community demanded project assistance because there were several leaky taps, worn out equipments, and bursts in pipe line etc. which the community wanted the Project to set right. It means setting right dilapidations in the system and replacing worn out equipments and components in the installation. In strict technical sense, improvement in service level was not required. The interest of the WS Project might have been establishing community-managed water supply system for which the Project Document warranted them to adopt a demand driven approach. The community demanded project assistance showing their ability and willingness to pay the financial contribution to become eligible to get project assistance. In other words, as far as the community members (or the Panchayat Functionaries) were concerned the agenda on the top of their mind was addressing the problem of leaking taps, replacing worn out equipments, and extension of pipe-line to unserved areas. As far as the Project staff were concerned, the agenda on the top of their mind was implementing 'the concept of demand driven approach and establishing community-managed water supply system'. The aspect of service level, or if the service level really required an improvement did not seem to be in the frame of things to discuss and decide.

\section{Cost of Wastage: The Unaccounted for Water}

As water is considered as a free gift of nature, the tendency to use water plentifully is still widely noticeable in several Tamil Nadu villages. Besides the most serious issue of safe water sources becoming increasingly depleted, there are several other implications to wasting water.

One such issue from the stand point of considering water as an 'economic good' is cost of unaccounted for water or cost of water wasted everyday insensible of the economic value of it. Especially in a piped water supply system, the water pumped from the ground whether they are used or wasted has an economic value - essentially as a service provided, by using electric power. It adds to cost of Operation and Maintenance.

The amount of water wasted in the study villages is found to be very high. All the 17 Village Panchayats put together, on an average 35 per cent of the water pumped is either excessively used or wasted. It means merely by being judicious in the use of water, each Panchayat has the potential of saving approximately one third of the expenses incurred on water service. The cost of wastage crosses Rs. 1 lakh per annum at least in six Panchayats, two of which are over Rs. 3 lakhs and Rs.5 lakhs. It is possible that these Village Panchayats are unaware of the cost of water wasted every year unnecessarily without anybody benefiting, for which the Village Panchayat is footing the bill. More so, the water users in these Panchayats might be unaware of the cost of water wasted every year. It is astounding to recollect here that (out of the 255 respondents interviewed) around 23 per cent of them have remarked that the water supply is inadequate. This gives a strong case for why water should be charged, including the users of the public fountains. It looks, without a speck of doubt that cutting down on the wastage can dramatically bring down the power Consumption Charges (EB Bill) and thus the cost of Operation of these Panchayats.

\section{Conclusion}

There is excessive physical infrastructure available for water

\begin{tabular}{|c|c|c|c|c|c|c|c|}
\hline \multirow[b]{2}{*}{ Village } & \multirow[b]{2}{*}{$\begin{array}{l}\frac{7}{0} \\
\frac{\pi}{\bar{Z}} \\
\frac{0}{0} \\
\frac{0}{0}\end{array}$} & \multirow{2}{*}{$\begin{array}{c}\text { Total Water } \\
\text { require } \\
\text { ment } \\
\text { ('000 Its) } \\
\text { (Col.2* 55) }\end{array}$} & \multirow[b]{2}{*}{$\begin{array}{c}\text { Actual Use } \\
\text { (Average of HSC \& PF) } \\
\text { LPCD }\end{array}$} & \multirow[b]{2}{*}{$\begin{array}{c}\text { Total Actual Use } \\
\text { ('000 Its) } \\
\text { Col. } 4^{\star} \text { Col. } 2\end{array}$} & \multirow[b]{2}{*}{$\begin{array}{c}\text { Wastage/Excess use } \\
\text { ('000 Its) } \\
\text { Col.5-Col.3 }\end{array}$} & \multicolumn{2}{|c|}{$\begin{array}{c}\text { Cost of wastage } \\
\text { (Calculated @Rs.3 per } 1000 \text { litres). }\end{array}$} \\
\hline & & & & & & $\begin{array}{l}\text { Per day (Rs) } \\
\quad\left(\text { Col. } 6^{\star} 3\right)\end{array}$ & $\begin{array}{c}\text { Per Annum } \\
\text { (Rs. akhs) } \\
\text { (Col.7*365) }\end{array}$ \\
\hline 1 & 2 & 3 & 4 & 5 & 6 & 7 & 8 \\
\hline Sathyavadi & 3314 & 182.27 & 83.50 & 276.72 & 94.45 & 283.35 & 1.03 \\
\hline Palakollai & 4347 & 239.085 & 77.50 & 336.89 & 97.81 & 293.42 & 1.07 \\
\hline Karuvepilanku & 3089 & 169.895 & 111.50 & 344.42 & 174.53 & 523.59 & 1.91 \\
\hline Koonakurichi & 1851 & 101.805 & 89.00 & 164.74 & 62.93 & 188.80 & 0.69 \\
\hline Valakollai & 1504 & 82.72 & 62.50 & 94.00 & 11.28 & 33.84 & 0.12 \\
\hline Keerapalay & 3747 & 206.085 & 139.00 & 520.83 & 314.75 & 944.24 & 3.45 \\
\hline valuthalampat & 8076 & 444.18 & 114.00 & 920.66 & 476.48 & 1429.45 & 5.22 \\
\hline Sirupalaiyur & 1239 & 68.145 & 82.50 & 102.22 & 34.07 & 102.22 & 0.37 \\
\hline Kannankudi & 1724 & 94.82 & 65.00 & 112.06 & 17.24 & 51.72 & 0.19 \\
\hline Vattathur & 1626 & 89.43 & 72.50 & 117.89 & 28.46 & 85.37 & 0.31 \\
\hline Ramanatham & 4745 & 260.975 & 55.00 & 260.98 & 0.00 & 0.00 & 0.00 \\
\hline Adari & 2658 & 146.19 & 92.50 & 245.87 & 99.68 & 299.03 & 1.09 \\
\hline Kanadamath & 1207 & 66.385 & 72.50 & 87.51 & 21.12 & 63.37 & 0.23 \\
\hline Pattur & 1162 & 63.91 & 90.00 & 104.58 & 40.67 & 122.01 & 0.45 \\
\hline Guruvappan & 832 & 45.76 & 107.50 & 89.44 & 43.68 & 131.04 & 0.48 \\
\hline Aranthangi & 2987 & 164.285 & 82.50 & 246.43 & 82.14 & 246.43 & 0.90 \\
\hline Sakkankudi & 1257 & 69.135 & 121.00 & 152.10 & 82.96 & 248.89 & 0.91 \\
\hline
\end{tabular}

Table 1.6: Cost of Unaccounted for Water. 
Citation: Ramesh R, Narayanasamy N (2010) Cost Of Unaccounted For Water - An Empirical Study In Tamil Nadu. J Waste Water Treatment Analysis 1:103. doi:10.4172/2157-7587.1000103

Page 8 of 8

supply in almost all the study villages. Hence, while implementing concepts like Demand Driven Approach, making the community contribute financially seem to give financial matters the over-riding priority. It blinds all other realities such as actual requirement as per technical standards, and responsibilities of Operation and Maintenance etc.

With regard to coverage, the entire 10,712 households in all the 17 Village Panchayats studied get drinking water either through House Service Connection (HSC) or through Public Fountain (PF). Handpumps are used as standby source only. There is hardly any village where they walk more than 200 metres to fetch water. In all the 17 Village Panchayats both PF users as well as the HSC holders are getting water supply more than what they should be getting as per the standard water supply norm of the government of Tamil Nadu. All the 17 Village Panchayats put together, on an average 35 per cent of the water pumped is either excessively used or wasted. It means merely by being judicious in the use of water, each Panchayat has the potential of saving approximately one-third of the expenses incurred on water service delivery.

\section{References}

1. Madeleen Wegelin (IRC) (1998) Community Management Models for Smal Scale Water Supply Systems", paper prepared for the workshop on: PublicPrivate Partnership in Service Provision for Community-managed Water Supply Schemes, Kakamega, 7-10 December 1998, Kenya.

2. Marieke T Boot (1991) The way to mix hygiene education with water supply and sanitation: Technical Paper Series (IRC), The Hague.

3. Yadava J S (1998) What People Know \& What They Practice (KAP Study Findings), Research paper presented at the National Seminar on Rural Sanitation, organized by Rajiv Gandhi National Drinking Water Mission, 9 - 10 July 1998, Vigyan Bhavan, New Delhi.

4. Government of India (2006) Economic Survey 2005-2006 Gol.

5. Ganapathy C (2003) Possible remedies to minimise contamination of groundwater in Cuddalore and Villupuram districts in Tamil Nadu, Danida: PMG, Cuddalore.

6. Ganapthy C (2006) Personal discussion the researcher had with Mr Ganapathy, Deputy Hydrogeologist TWAD Board, December 2006, Salem.

7. Government of Tamil Nadu. 2005. GoTN, Tamil Nadu Economic Appraisal, 200405 Chennai.

8. Ramesh R, Manivel S (2005) Demand Driven Approach - A Development Imperative- Paper presented at the National Seminar on Community Outreach Methodologies held at Gandhigram Rural Institute from 27th to 29th January 2005. Gandhigram

9. Ramesh R. (2002) Marketing Sanitation: Ideas that Sell, Working Paper prepared based on the experiences in Danida WS Project-TN, (presented at Danida staff workshop) DTF, Cuddalore.

10. Ramesh R (2003) Domestic Water Supply System in Rural Tamil Nadu paper presented at the AICTE Sponsored National Conference on 'Interlinking of Indian Rivers - Problems and Perspectives Organised by the Mahendra Engineering College, 20 - 22nd October 2003, Namakkal.

11. Attanayake, Jayasiriwardene (1996) System Development for Future Sustainability, 22nd WEDC Conference on Reaching the Unreached: Challenges for the 21st Century, New Delhi.
12. Durgaprasad P (2003) Drinking Water: Management Strategies and Future Agenda, Kurukshetra 51: 12-15.

13. IRC (1995) Making Yours Water Supply Work: Operation and Maintenance of Small Water Supply Systems, IRC, The Hague, The Netherlands.

14. Government of India (2004) Accelerated Rural Water Supply Programme, Rajiv Gandhi Drinking Water Mission, Annual Report, Chapter - 7, New Delhi.

15. Lennart Nilsson (2002) Village based Management of water supply and sanitation in Tamil Nadu", 28th WEDC Conference, Kolkata.

16. Danida (1996) Project Document for Danida GoTN Water and Sanitation Demand Project, April, Chennai.

17. Francois Brikke (2002) Operation and Maintenance of Rural Water Supply and Sanitation Systems: A Training Package for Managers and Planners, 1:45, WHO Switzerland.

18. Danida (1992) Water Supply and Sanitation: Sector Policies, Ministry of Foreign Affairs, DK-1448, Copenhagen.

19. Danida (2001) Project Resource Book, Volume - 1, Overview and Planning Government of Tamil Nadu / Danida, 2001, December, Cuddalore.

20. Danida (2001) GoTN/ Danida Resource Book - Vol.III Implementation of Water Works December 2001, Cuddalore.

21. Jeremy Ockelford, Jan-Willem Rosenboom, Bent Kjellerup (1996) A VLOM Framework for Cambodia, 22nd WEDC Conference on Reaching the Unreached: Challenges for the 21st Century, New Delhi.

22. Kulasekaran A (2001) Contamination of Water Sources and Rectification Methods, TWAD Board, Chennai.

23. TWAD (2002) MD-TWAD Circular/ Design Criteria Lr.No.1202/AE3/PM/R/2002 dt. 21.02.2002, Chennai.

24. WHO (2000) Operation and Maintenance of Rural Water Supply and Sanitation Systems - A Training Package, WHO, Geneva. p.86

25. Danida (2004) Management of Water Supply and Sanitation: A guide to Village Panchayats, March 2004, Danida: PMG, Cuddalore.

26. World Bank (2006) Approaches to Private Participation in Water Services: A Too Kit, The World Bank, Washington DC.

27. World Bank (2003) Sustainability, Planning, and Monitoring in Community Water Supply and Sanitation, The World Bank, New Delhi.

28. Government of Tamil Nadu (2002) GoTN: TWAD MS.No.30/P\&D/JE6/ 2002/ Population Forecast dated 8.4.2002", Chennai.

29. Ben Page (1996) Ergonomics and Human Water Carrying, 22nd WEDC Conference on Reaching the Unreached: Challenges for the 21st Century, New Delhi.

30. Samuel Paul, Suresh Balakrishnan, Gopakumar K, Sita Sekhar, Vivekananda M (2004) State of India's Public Services, Economic and Political Weekly. February 28, 2004.

31. Government of Tamil Nadu (1992) GoTN: Danida, Block Groundwater Potentia and Stage of Groundwater Development - as on January 1992, Cuddalore district.

32. Government of Tamil Nadu (1998) GoTN: TWAD Ms. No.231/ Circular on Rura Water Supply Norms dated 14.5.1998, Chennai.

33. Government of Tamil Nadu (2004) Groundwater - Estimation of Groundwate resources as per GEC Methodology, PWD, G.O. (Ms)No.51 dated 11.2.2004. Chennai. 